\title{
'WE ARE A STORY-TELLING PEOPLE': AN EXPLORATION OF THE ORIGIN TALES IN THE ORAL NARRATIVES OF THE NAGAS AND THE KHASIS OF INDIA'S NORTH EAST
}

\section{Dr. Payel Dutta Chowdhury}

\begin{abstract}
In the absence of a written literature and language for ages, the oral tradition was one of the distinguishing characteristic features of the various tribes of Nagaland and Meghalaya. In the case of the Khasis of Meghalaya, "...their alphabet is of very recent history, no older than when Thomas Jones, the Welsh Presbyterian missionary, introduced the Roman script in 1842, to form the essentials of the Khasi written word." (Nongkynrih vii) For the Nagas, even the oral dialects spoken by the different indigenous tribes are different and hence, it was not an easy task to keep the oral tradition alive amidst so much of diversity.
\end{abstract}

The origin tales that find mention in the oral narratives of both the Nagas and the Khasis play an important role in the comprehension of the unique culture and tradition of both the tribes. This paper is an attempt to explore the tales related to the origin of the Nagas and the Khasis, to explore their rich oral tradition, how these tales mirror the cultural identity of these tribes which have undergone several changes in today's time and most importantly, to read in between the lines of the tales to explore their significance vis-à-vis the social and cultural make-up.

Keywords: Nagas, Khasis, Origin Tales, Oral Narratives, Story-telling

It is indeed amazing to note that even in the absence of a written language and literature for ages, the Nagas and Khasis could keep their oral tradition alive by passing it from one generation to the other. The numerous legends, myths, folk tales, folk songs, etc. were a part and parcel of the education that was imparted to every person in the family as well as in the dormitories. The father or the grandfather at 
home was usually the family storyteller and a common sight during many a winter night would be a group of young children huddled together near the fireplace listening to the amazing stories of the bygone days. Similarly, for the Nagas, the oral tradition was kept alive in the dormitories where young boys and girls would get to know the age-old beliefs, legends and folk tales of their tribes. In this context, it is important to note that there exist several dialects among these tribes and hence, it was not an easy task to keep the oral tradition alive amidst so much of diversity.

Even though several decades have passed after the introduction of the written form of discourse among the Nagas and the Khasis, still there are only a handful of records which exist on their folklores. This highlights the fact that much of the folklores of the Nagas and the Khasis still exist in the oral form. Few British administrators and anthropologists, such as, J.P. Mills and J.H. Hutton have recorded the folk tales of some Naga tribes. It is heartening to see the efforts of some scholars and ethnographers of today's times, such as, Temsula Ao and Sujata Miri who have also recorded the folklores of their tribes in the written form. Major P.R.T. Gurdon, Deputy Commissioner Eastern Bengal and Assam Commission, and Superintendent of Ethnography in Assam, has recorded some important folktales of the Khasis in English as well as in the Khasi language which has been published under the orders of the Government of Eastern Bengal and Assam. It is heartening to see the efforts of some scholars and ethnographers of today's times, such as, Kynpham Sing Nongkynrih and Bijoya Sawian who have also recorded the folklores of their tribes in the written form.

Amidst a variety of subjects which form the basis of the oral narratives of the Nagas and the Khasis, the origin tales of the tribes play a predominant role in the comprehension of their unique culture and tradition. A common subject matter of the folk tales of the Nagas is the narratives on the origin of various clans and tribes. Reflecting on the lack of concrete proof about the origins of the Nagas, M. Horam states, "...the Nagas of our time are unable to give any accurate information relative to the history of this exotic people: neither did those who lived thousand years ago leave any accounts from which even a hypothesis could be formed. Though traditional songs and legends tell us their vague history of the past, they do not 
provide much light...All plausible theories on this people are based on conjectures and fertile human imagination." (Horam, Old Ways 11).

In the absence of authentic information, the origin myths of the Nagas are juxtaposed with elements of the supernatural and various fanciful ideas. These myths find place in various folk tales and "...have all the ingredients of the imaginative, the supernatural and the real in the form of tangible images or landmarks." (Sekhose 128) Some of these origin tales are similar whereas, others are as distinct as possible from each other. The tale of origin among the Ao Nagas highlights that the Ao ancestors emerged from six stones in a place called Lungertok, the remnants of which they claim can still be seen above a village called Chungliyimiti. The tale no doubt leaves a lot of things unexplained and seems to border on the realm of the fanciful but for the Aos there was no second thought about it and anyone who would raise doubts regarding this story was taken to task. Sujata Miri records an instance when a man opposed this origin story - "A man from Changki village named Ajangtai expressed the view that Aos did not emerge from the six stones in Chungliyimti but belonged to the Mongolian race and must have migrated from somewhere. On hearing this, the Aos imposed a fine of Rs. 50 on him!" (Miri, World-view 30)

The different clans among the Aos invariably trace their origin to one of the forefathers who emerged from these stones. This origin myth serves the purpose of establishing the culture of exogamous marriage established by the first fathers and is still continued in today's time as a strict Ao-Naga customary practice and social custom. Some of the other Naga tribes believe in similar myths regarding their origin and yet there are several others who trace their origin to sources completely different from the six stones at Lungterok. The Angamis, for instance, have a different say regarding their origin and hence, "...Lungterok legend was not known to the Angamis and other western Nagas....Kepezoma and Kupepfuma, the two divisions of the Angami Nagas, according to a legend, descended from two brothers who came out of the earth....they believe that the prints of the hand, feet and the knees of their ancestors may still be found in front of the hole from which they emerged." (Kumar 55) 
In Hutton's record of the origin tale of the Angami Nagas, the story 'The Naga and the Plainsman' is of two brothers who separate their ways and in Hutton's translation a difference is drawn between the two with a reason as to "...why the Nagas are poorer in knowledge and cunning than the men of the plains." (Hutton, Angami Nagas 261) The Sema Nagas have a tale on the origin which highlights that ane point of time, the Angamis, the Aos, the Lothas and the Semas had the same ancestors and in fact, the same mother. The narrative also records the inclusion of the 'Foreigner' along with the names of the tribes which make us wonder if that is a mention of the British colonizer. In that sense, the story seems to highlight a time period when human civilization did not consist of the many divisions as we have in today's time based on race, class, tribe, etc. The tale ends with the separation of the tribes after a period of living together. Another origin narrative is found in the folk tales of the Liangmai Nagas. According to the tale, a group of Nagas migrated from their original place in search of fertile lands. They stopped at a place called Makhiang according to the sign that the cow, gifted by their grandfather, provided them. After sometime when the place started becoming over populated, some brothers from the group went off to other directions to search for place of living. A big pearl tree which had eight branches grew from the walking sticks that each brother had planted in the ground before leaving the place. This is believed to be the origin of the different clans among the Liangmai Nagas. Among the Lotha Nagas exist an origin story called 'The Story of Lankongrhoni' which is of how a man named Arilao was killed by other men of his community due to jealously. His mother takes revenge of the death and kills all the children of the village. The only people who escaped were a brother and sister who later on got married and it is from them that all future progeny was born. The origin tales of the Nagas, thus, are an important part of their oral tradition and vary from tribe to tribe.

This group of origin tales also consists of stories on the origin and naming of certain clans and villages. J.P. Mills records a Lotha folk story called 'The Origin of the Kithang Clan' which focuses on how two different clans came together after a fight and became one clan. In the Ao Naga folk tradition, there exists record of two stories on the supposed derivations of names of villages. The first one titled 'How Koio got its name' is of the death of a girl due to her step mother's torture. The girl's father gets to know of this matter, transforms to a snake and devours the cunning step 
mother. In a narrative which begins on the tone of our regular 'Cindrella' fairytale, the ending is one of justice and celebrates the immediate action of the father figure which was surprisingly missing in the case of the 'Cindrella' story. The other Ao story is of a man who killed his lover and how the village, Salunaru, derived its name from the dead girl. Two tales among the Semas also focus on the origin of different clans. The first one titled 'The Yepothomi' narrates the tale of six brothers who lived together until one day when one of the brothers kills another one. This led to their separation and the subsequent origin of different clans among the Sema Nagas. The story titled 'The Yepothomi and the Ayemi' is similar to the other one and highlights that once upon a time these two clans were one. It focuses on the story of two brothers and how the elder one tricked the younger and led him to the forest where he was killed by enemies. This in turn led to the separation of the clans. Yet another story among the Semas records how different clans got their names. This narrative gives a literal translation of the names of tribes and clans and relates the meaning to stories behind it. Similar to the origin tales of the Naga tribes, the narratives of the origin and naming of various clans and villages also form a part of their oral tradition.

Similar to the Nagas, a popular subject matter of the folk tales of the Khasis is the narratives on the origin of the tribe and the earth. Reflecting on the belief of the Khasis about their origins, Pascal Malngiang states, "Today with the growth of science and research, a number of investigations have been made to trace the origin of the Khasi. However, despite such attempts the Khasi holds on to his own views about the origins of his race. He believes that the Khasi was directly created by God and placed in these hills, of which the most sacred ones are the Sophet Bneng (The Navel of Heaven) peak in the north, the Diengiei (the sign of sin) peak in the west, and the Shyllong (Lum Shyllong) peak in the southern part of Shillong." (Malngiang 9)

This belief finds place in the tale of the seven clans popular among the tribe which explains their origin. In an Adam and Eve like situation, the first woman and man created by God, according to the Khasis were called Ramew and Basa. What is striking in the narrative is the benevolence of the Khasi God, $U$ Blei, who is gracious to understand the urge of his first creations to have children. The original sin here is not committed by Ramew and Basa or their five children - Sun, Moon, Water, Wind and Fire. It is the human beings on earth, the seven clans who were given the 
responsibility of taking care of the earth, who rebel against the creator and thus, lose the chance of entering heaven whenever they wished through the 'golden ladder'. The loss of $U$ Blei's love and the severing of the ties with the other nine clans in heaven is regarded as the end of the 'Golden Age'. The seven clans who remained on earth are identified as the seven sub-tribes of the Khasi people; i.e., the Khynriam, Pnar, Bhoi, War, Maram, Lyngngam and Diko. Largely symbolic in nature, the narrative of the seven clans brings to forefront several important ideas related to the cultural beliefs of the Khasi people. Kynpham Sing Nongkynrih, while explaining the allegorical nature of the tale, says, "...when the Khasis speak of Ka Jingkieng Ksiar (the Golden Ladder) located at Lum Sophet Bneng (the Mount of Heaven's Navel) and how the Khasi people, in a Golden Age of their existence, used to travel between heaven and earth through the Golden Ladder, they only mean to impress on the listener that the Golden Ladder is actually a golden heart, a virtuous soul, which stands as the only link between Man and God....It is very important, therefore, to understand the allegorical nature of the stories, so that they are not simply read a fantastic tales from yet another exotic culture." (Nongkynrih ix, $x$ )

The tale of the seven clans, thus, not only gives an explanation about the origin of the Khasi people but also highlights the various beliefs of the tribe. In a slightly different narrative, the severing of man's ties with god is explained by the interference of $U$ lakjakor, a Satan-like figure, who tempted the human race to rebel against their creator and fell the giant Diengiei tree. Human beings "...did not realize that the cutting down of the sealed divine symbolic tree was a violation of God's commandment and amounted to committing a sin." (Snaitang 159) The theme of man's selfishness and his temptation to go against the tenets of his creator runs all throughout the tale. Hence, the use of the symbol of the 'golden ladder' signifying the link between man and God or the severing of the Diengiei, the oak tree, which is symbolically known as the 'Tree of Gloom' signifying the severing of the umbilical cord between the mother and the child, are instructional in purpose of letting the Khasi people remember the dire consequences of leaving God and with that, all that is good and just. An important aspect of the origin story about God's removal of the 'golden ladder' and man's felling down the Diengiei is related to conservation of ecology and can be read as the starting point of man's severed ties also with nature. Hence, it is believed that the origin story points out that "...human beings, who did no 
longer see the connection between their existence and nature's essence, appeared to have lost the ecological conscience. There was no more a sense of guilt in felling down of trees." (Snaitang 159) Another interesting aspect of the tale is the mention of the tiger who was initially given the responsibility of ruling the earth even before it was given to the human beings. The tiger's despotism ultimately made $U$ Blei to rethink his decision and allow the seven clans to visit earth through the 'golden ladder' to take care of it. This must have been the birth of the animosity between the animal and human beings. Unlike the folktales of the Nagas, where the tiger finds a special mention as the brother of man, in the Khasi tales, the fierce animal is always the enemy. Further in the tale of the seven clans, when men ultimately mastered the strategy of felling Diengiei, it also led to the tiger being bruised and foiled his plan of preying on man in the darkness. The tale of the seven clans, narrated with slight twists here and there, remain to be the most important explanation among the Khasis regarding their origin.

Another tale which plays an important role in the explanation of the Khasi culture is related to the origin of the oral tradition among the tribe. The tale of the lost manuscript takes forward the narrative of the seven clans, who when settled on earth for a long time, had started feeling the absence of God's benevolence. It highlights the reasons for the simple way that the Khasi religious doctrines teach the basic ideas of their culture and tradition. In prioritizing on simplicity, the tale brings to light how "...it is that personalization of the teachings and the divine laws that makes the worship of God, in every Khasi household today, a very personal matter, taking place in the heart of each individual and not in any church or temple." (Nongkynrih 19) The tale is in itself an explanation of the tradition of storytelling among the Khasi people. Even though there exist various opinions on the origin of the Khasis, one important tradition does point at the flood which finds mention in the folktale. Major Gurdon, while discussing on the various probabilities of the origin of the tribe, mentions this particular belief of "...the north as the direction from which they (Khasis) migrated, and Sylhet as the terminus of their wanderings, from which they were ultimately driven back into their present hill fastnesses by a great flood..." (Gurdon 10) Thus, the belief of the lost manuscript connected to the origin of the oral tradition among the Khasi people becomes a part and parcel of their cultural identity. 
Equally important in the tradition of the Khasi folktales is the narrative of the very origin of the earth the way it is now. Connected to the story of the seven clans, this tale highlights that initially "...the earth was just one flat, vast stretch of land" (Sawian 3 ) without any mountains or valleys. The tale highlights the way that the culture of burning the body of the dead originated among the Khasi people. It also narrates how with the last rites of the first mother having been performed, the earth was converted to what it is at present with beautiful mountains, valleys, trees and shrubs.

The origin tales of the Nagas and the Khasis, thus, mainly concentrate on explanations of the tribe's presence on the earth, and the way that their culture and traditions took shape. The tales are laden with deeper meanings and need to be read between the lines to decipher the instruction and values which form the core of their way of life. The rich body of folk narratives among these tribes brings out various unique beliefs and traditions of the tribes. The origin tales serve the purpose of giving an explanation to the existence of these tribes which even though in many cases, quite fantastical, is believed by the larger community and passed on to the younger generation and form a part of their existence. 


\section{Works Cited}

Gurdon, Major P.R.T. The Khasis. Cosmo Publications, 1975. (First published in 1907)

Horam, M. Nagas: Old Ways New Trends. Cosmo Publications, 1988.

Hutton, J.H. The Angami Nagas. OUP, 1969. (First published by Macmillan Co. Ltd, 1921)

Kumar, B.B. Naga Identity. Concept Publishing Company, 2005.

Malngiang, Pascal. Aspects of Khasi Philosophy. Seven Huts Enterprise, 1991.

Miri, Sujata and Karilemla. Ao Naga World-View - A Dialogue. Indian Council of Philosophical Research and D.K. Printworld (P) Ltd., 2015.

Nongkynrih, Kynpham Sing. Around the Hearth - Khasi Legends. Penguin Random House India Pvt. Ltd., 2007.

Sawian, Bijoya. Khasi Myths, Legends and Folktales. Ri Khasi Press, 2006.

Sekhose, Jano L. "Idea of Evil and Fear of the Supernatural among the Nagas with Special Reference to Angami Tribes”. Biswas, Prasenjit and C. Joshua Thomas

(Ed.). Construction of Evil in North East India: Myth, Narrative and Discourse. SAGE Publications, 2012.

Snaitang, O.L. "An Exploration of Dimensional Perspectives of Devils and Evil Designs among the Khasi-Jaintia People of Meghalaya." Biswas, Prasenjit and C. Joshua Thomas (ed.) Construction of Evil in North East India - Myth, Narrative and Discourse. SAGE Publications, 2012.

\section{Dr. Payel Dutta Chowdhury Professor and Director School of Arts \& Humanities REVA University Bangalore, India Email ID: payeldutta.c@gmail.com}

